Bangladesh J. Bot. 42(1): 65-71, 2013 (June)

\title{
EFFECTS OF GROWTH REGULATORS ON SEED GERMINATION, SEEDLING GROWTH AND SOME ASPECTS OF METABOLISM OF WHEAT UNDER ALLELOCHEMICAL STRESS
}

\author{
Bengu TuRKyiLmaz UnAL* \\ Nigde University, Ulukısla Vocational School, 51900 Ulukısla-Nigde, Turkey \\ Key words: Allelochemical stress, Growth regulators, Seed germination, Metabolism
}

\begin{abstract}
Effects of growth regulators on seed germination, seedling growth and some aspects of metabolism of wheat under allelochemical stress due to oleander and walnut leaf (extract and powder) were investigated. All parameters e.g. seed germination, seedling growth, leaf pigments except the proline content reduced significantly under stress. On the contrary, $\mathrm{GA}_{3}$ and IBA showed alleviating activities. The alleviation effect of $\mathrm{GA}_{3}$ was higher than that of IBA.
\end{abstract}

\section{Introduction}

The chemical interactions that occur among living organisms including plants, insects and microorganisms are called allelopathy which induces direct or indirect harmful or beneficial effects through the production of allelochemicals (Putnam 1985, Whittaker and Feeny 1971). Allelochemicals are known to affect seed germination, growth, distribution and reproduction of a number of plant species (Inderjit and Malik 2002).

Allelopathic effects have been reported in many plant species including crops and weeds (Kazincki et al. 1997, Rice 1984, Turk and Tawaha 2002, Uygur and Iskenderoglu 1997). Oleanders (Nerium oleander L.) and walnuts (Juglans nigra L.) are common plants in Mediterranean and the Aegean region of Turkey. They produce a large number of allelochemicals ( Matok et al. 2009, Rajyalakshmi et al. 2011).

Plant growth regulators are used to ameliorate stress impact due to allelochemicals (Terzi and Kocaçalışkan 2010). However, reports on ameliorating effect of growth regulators on plant growth and metabolism under stress due to allelochemicals is scanty. In the present study, ameliorating effects of growth regulators e.g., $\mathrm{GA}_{3}$ and IBA on seed germination, seedling growth, total chlorophyll, carotenoids and proline contents of wheat seedling under allelochemical stress due to oleander and walnut leaf (extract and powder) were investigated.

\section{Materials and Methods}

Seed of wheat (Triticum aestivum L.) were obtained from the suppliers TASACO, Antalya, Turkey. One gram of air-dried plant leaf litter was separately soaked in one litter of double distilled water for $12 \mathrm{~h}$ at room temperature. Then, the mixtures were filtered through Whatman No.1 filter paper to obtain the oleander and walnut leaf extracts. Also, 10 ppm GA 3,20 ppm GA 3 , $10 \mathrm{ppm}$ IBA and $20 \mathrm{ppm}$ IBA solutions in distilled water were prepared. Seeds were surface sterilised with $5 \%$ sodium hypochloride. Twenty five wheat seeds were given in each Petri dish (10 cm dia) provided with two layers filter paper saturated with $5 \mathrm{ml}$ of distilled water (control),

*Author for correspondence: <bngtrkylmz@yahoo.com.tr>. 
with $2.5 \mathrm{ml}$ of leaf extract (oleander-O, walnut-W) and $2.5 \mathrm{ml}$ distilled water or $2.5 \mathrm{ml}$ of leaf extract and $2.5 \mathrm{ml}$ growth regulators. The Petri dishes were placed in a growth chamber at $25 \pm$ $1^{\circ} \mathrm{C}$ and light/dark regime of $16 / 8 \mathrm{hrs}$. Seeds were considered germinated after emergence of root from the caryopses and germination count was recorded up to one week. After one week, shoot and root lengths and fresh weight of the seedlings were measured. Dry weights were recorded after two days oven-drying at $65^{\circ} \mathrm{C}$. Experiment was replicated four times.

In another experiment, wheat seeds were sown in pots $\left(20 \times 30 \mathrm{~cm}^{2}, 25\right.$ seeds for each $)$ filled with perlite and $3 \mathrm{~g}$ leaf powder (oleander or walnut) except control. Seedlings grown in a growth chamber (light/dark regime of $16 / 8 \mathrm{hrs}$ at $25 \pm 1{ }^{\circ} \mathrm{C}$, relative humudity of $60-70 \%$ and light intensity $350 \mu \mathrm{M} / \mathrm{m}^{2} / \mathrm{s}$ ). Seedlings were irrigated (Hoagland and Arnon 1950) with $200 \mathrm{ml}$ distilled water every other day in all groups, with $200 \mathrm{ml}$ Hoagland solution and $200 \mathrm{ml}$ distilled water in control group or with $200 \mathrm{ml}$ Hoagland solution and $200 \mathrm{ml}$ growth regulator solution (10 and 20 ppm $\mathrm{GA}_{3}, 10$ and $20 \mathrm{ppm} \mathrm{IBA)} \mathrm{in} \mathrm{treatment} \mathrm{groups} \mathrm{once} \mathrm{a} \mathrm{week} \mathrm{for} \mathrm{four} \mathrm{weeks.} \mathrm{After}$ harvesting, plant samples were analyzed for growth parameters, leaf pigments and proline contents. Vigour index was determined according to Abdul-Baki and Anderson (1973) as vigour index: per cent germination $\times$ seedling length. For leaf pigments, $0.5 \mathrm{~g}$ fresh leaf samples of fourweek-old-seedlings of wheat were extracted with $5 \mathrm{ml} 80 \%$ acetone and absorbance of supernatants were measured spectrophotometrically at $652,665 \mathrm{~nm}$ for chlorophylls and at 450 $\mathrm{nm}$ for carotenoids (Lichtenthaler 1987). Proline was determined in fresh leaf sample according to the modified method of Bates et al. (1973). Data were analyzed using one-way ANOVA followed by Fisher's LSD post-hoc test. The criteria for statistical significance were set at $\mathrm{p}<0.05$ and 0.01 .

\section{Results and Discussion}

Germination of wheat seeds was inhibited slightly by oleander and walnut compared to control (Table 1). However, treatments of wheat seeds with $\mathrm{GA}_{3}$ and IBA significantly alleviated this inhibition. $\mathrm{GA}_{3}$ was found more effective than IBA to alleviate the inhibitory effect on seed germination (Table 1). Alleviation of inhibitory effect by $\mathrm{GA}_{3}$ was $4.3 \%$ in oleander and $6.5 \%$ in walnut. Seedling vigour index decreased with oleander and walnut leaf extract and increased with extract +10 ppm $\mathrm{GA}_{3}$ and extract $+20 \mathrm{ppm} \mathrm{GA}$ applications compared to the control (Table 1). Both root and shoot elongation of seven-day-old-seedlings of wheat decreased with oleander and walnut leaf extract compared to the control. This inhibition of root and shoot elongation was alleviated by $\mathrm{GA}_{3}$ reatments. IBA treatments decreased root elongation but increased shoot elongation. On the other hand, generally growth regulators alleviation of oleander and walnut stress was higher on shoot elongation than on root elongation (Table 1). Similarly, fresh and dry weights of roots and shoots of seven-day-old-seedlings of wheat were also reduced by oleander and walnut leaf extract and the effect was alleviated by growth regulators. The greatest alleviation was achieved with oleander extract $+10 \mathrm{ppm}$ IBA treatment $50 \%$ in shoot fresh and shoot dry weight, in root fresh weight and root dry weight and walnut extract $+10 \mathrm{ppm}$ IBA with treatment alleviation of $29.23 \%$ in shoot fresh weight, $22.22 \%$ in shoot dry weight, $16.24 \%$ in root fresh weight and $21.74 \%$ in root dry weight (Table 2).

Previous reports showed that allelochemicals of walnut and oleander inhibited germination and seedling growth of several plant species (Matok et al. 2009, Qian et al. 2010, Rajyalakshmi et al. 2011) and growth regulators can significantly overcome allelochemical stress on seed germination and seedling growth (Terzi and Kocaçalışkan 2010). It was indicated that oleander and walnut leaf extracts inhibited germination and seedling growth of wheat, and growth regulators overcome this allelochemical stress (Tables 1,2). 
Oleander and walnut extracts caused a reduction in seedling vigour index of wheat compared to the seedlings grown with distilled water only (Table 1). Djanaguiraman et al. (2005) found a similar type of result in rice, sorghum and blackgram due to Eucalyptus globulus. The reduction in

Table 1. Effects of growth regulators on seed germination, root and shoot growth of seven-day-oldseedlings of wheat grain under allelochemical stress due to oleander and walnut leaf extracts.

\begin{tabular}{|c|c|c|c|c|}
\hline Treatments & $\begin{array}{l}\text { Germination } \\
(\%)\end{array}$ & $\begin{array}{l}\text { Vigour } \\
\text { index }\end{array}$ & $\begin{array}{l}\text { Root length } \\
\text { (cm) }\end{array}$ & $\begin{array}{l}\text { Shoot length } \\
(\mathrm{cm})\end{array}$ \\
\hline Extract +0 & $93 \pm 1.26$ & 1780,95 & $9.95 \pm 1.20$ & $9.20 \pm 1.00$ \\
\hline Extract +10 ppm GA 3 & $97 \pm 0.98^{* *}$ & 2716,97 & $12.50 \pm 0.97$ & $15.51 \pm 2.80^{* *}$ \\
\hline Extract $+20 " \mathrm{GA}_{3}$ & $96 \pm 0.82 * *$ & 2271,36 & $12.33 \pm 0.65$ & $11.33 \pm 1.23^{*}$ \\
\hline Extract +10 " IBA & $96 \pm 0.82 * *$ & 1909,44 & $8.82 \pm 1.90$ & $11.07 \pm 0.82$ \\
\hline Extract +20 " IBA & $95 \pm 0.50^{*}$ & 1673,90 & $6.60 \pm 1.00 * *$ & $11.02 \pm 0.66$ \\
\hline Extract +0 & $92 \pm 0.82$ & 1920,04 & $10.37 \pm 2.02$ & $10.50 \pm 1.14$ \\
\hline Extract +10 ppm $\mathrm{GA}_{3}$ & $98 \pm 0.58^{* *}$ & 2779,28 & $12.35 \pm 0.81$ & $16.01 \pm 2.27 * *$ \\
\hline Extract $+20 " \mathrm{GA}_{3}$ & $98 \pm 1.00^{* *}$ & 2398,06 & $11.78 \pm 0.97$ & $12.69 \pm 0.63^{*}$ \\
\hline Extract +10 " IBA & $96 \pm 0.82 * *$ & 2069,76 & $9.59 \pm 1.66$ & $11.97 \pm 1.02$ \\
\hline Extract +20 " IBA & $95 \pm 0.96^{* *}$ & 1775,55 & $6.86 \pm 1.64 * *$ & $11.83 \pm 0.93$ \\
\hline $\begin{array}{l}\text { Control (Seeds soakd with } \\
\text { distilled water only) }\end{array}$ & $96 \pm 0.82 * *$ & 2230.08 & $11.31 \pm 3.09$ & $11.92 \pm 0.67^{*}$ \\
\hline $\mathrm{LSD}_{0.01}$ & 2.245 & - & 3.355 & 2.781 \\
\hline $\mathrm{LSD}_{0.05}$ & 1.667 & - & 2.491 & 2.065 \\
\hline
\end{tabular}

LSD test was applied. * and $* *$ indicate at significant $\mathrm{p}<0.05$ and 0.01 , respectively.

Table 2. Effects of growth regulators on root and shoot fresh and dry weight of seven-day-old-seedlings of wheat grain under allelochemical stress due to oleander and walnut leaf extracts.

\begin{tabular}{|c|c|c|c|c|}
\hline Treatments & $\begin{array}{l}\text { Root fresh } \\
\text { weight }(\mathrm{g})\end{array}$ & $\begin{array}{l}\text { Shoot fresh } \\
\text { weight }(\mathrm{g})\end{array}$ & $\begin{array}{l}\text { Root dry } \\
\text { weight (g) }\end{array}$ & $\begin{array}{l}\text { Shoot dry } \\
\text { weight }(\mathrm{g})\end{array}$ \\
\hline Extract +0$)$ & $0.131 \pm 0.020$ & $0.058 \pm 0.013$ & $0.025 \pm 0.005$ & $0.008 \pm 0.002$ \\
\hline Extract +10 ppm $\mathrm{GA}_{3}$ & $0.134 \pm 0.022$ & $0.087 \pm 0.017^{*}$ & $0.027 \pm 0.004$ & $0.012 \pm 0.002 *$ \\
\hline Extract $+20 " \mathrm{GA}_{3}$ & $0.133 \pm 0.024$ & $0.072 \pm 0.012$ & $0.026 \pm 0.005$ & $0.010 \pm 0.002$ \\
\hline Extract +10 " IBA & $0.139 \pm 0.017$ & $0.073 \pm 0.008$ & $0.028 \pm 0.004$ & $0.010 \pm 0.002$ \\
\hline Extract +20 " IBA & $0.135 \pm 0.022$ & $0.065 \pm 0.013$ & $0.027 \pm 0.005$ & $0.009 \pm 0.003$ \\
\hline Extract +0 & $0.117 \pm 0.019$ & $0.065 \pm 0.014$ & $0.023 \pm 0.004$ & $0.009 \pm 0.003$ \\
\hline Extract +10 ppm GA 3 & $0.119 \pm 0.017$ & $0.078 \pm 0.011$ & $0.024 \pm 0.004$ & $0.010 \pm 0.001$ \\
\hline Extract $+20 " \mathrm{GA}_{3}$ & $0.116 \pm 0.021$ & $0.066 \pm 0.013$ & $0.023 \pm 0.003$ & $0.009 \pm 0.002$ \\
\hline Extract +10 " IBA & $0.136 \pm 0.021$ & $0.084 \pm 0.013$ & $0.028 \pm 0.005$ & $0.011 \pm 0.001$ \\
\hline Extract +20 " IBA & $0.131 \pm 0.020$ & $0.069 \pm 0.012$ & $0.026 \pm 0.004$ & $0.010 \pm 0.002$ \\
\hline $\begin{array}{l}\text { Control (Seeds soaked with } \\
\text { distilled water only) }\end{array}$ & $0.136 \pm 0.017$ & $0.071 \pm 0.017$ & $0.027 \pm 0.007$ & $0.010 \pm 0.003$ \\
\hline $\mathrm{LSD}_{0.01}$ & 0.225 & 0.225 & 0.007 & 0.007 \\
\hline $\mathrm{LSD}_{0.05}$ & 0.167 & 0.167 & 0.005 & 0.005 \\
\hline
\end{tabular}

LSD test was applied. * and $* *$ indicate at significant $\mathrm{p}<0.05$ and 0.01 , respectively. 


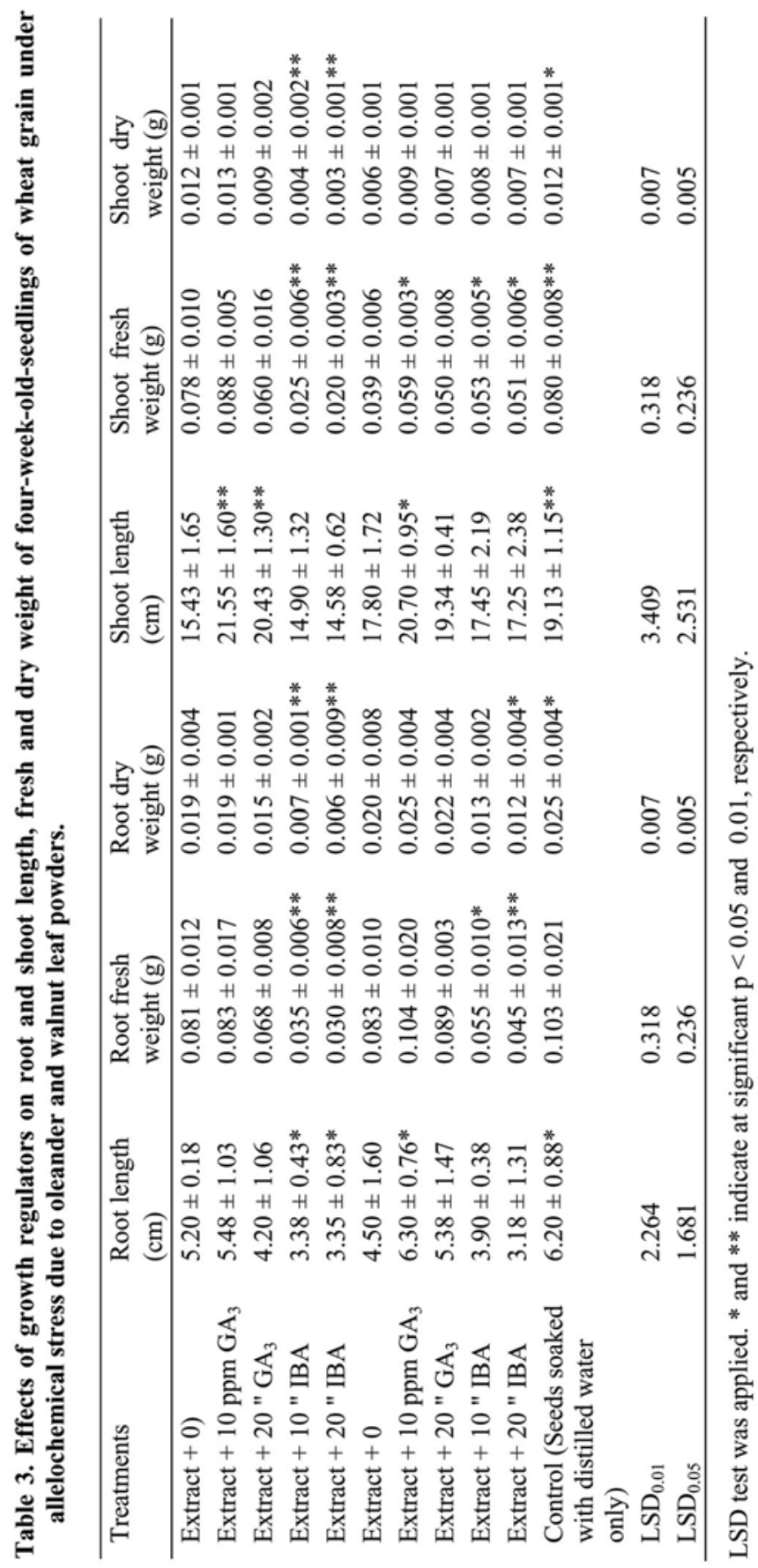


vigour index in wheat may be due to reduced germination and seedling length (Singh and Rao 2003). Pretreatments of Agropyron elongatum and Bromus inermis seeds with the chemical stimulators e.g., $\mathrm{GA}_{3}$ before planting could significantly reduce the negative effect of allelopathic compounds in Thymus kotschyanus during the germination stage too (Saberi et al. 2011).

Both elongation and fresh-dry weights of four-week-old-seedlings of wheat were also reduced by oleander and walnut leaf powders, and the $\mathrm{GA}_{3}$ and IBA alleviated these parameters. The most effective treatments in alleviating inhibition are oleander extract $+10 \mathrm{ppm}$ GA and Walhut extract $+10 \mathrm{ppm}$ GA in root length, fresh and dry weights, also in shoot length, fresh and dry weights (Table 3). Total chlorophyll was reduced by $23.22 \%$ in oleander and $36.55 \%$ in walnut leaf powder. Besides, carotenoid amounts were decreased by $2.84 \%$ in oleander and $17.08 \%$ in walnut leaf powder compared to the control. The greatest alleviation was achieved with oleander +10 ppm GA (23.20\%) and Walnut +10 ppm GA (13.93\%) in total chlorophyll and in carotenoid amounts $(2.07 \%)$ (Table 4). Proline contents of wheat were affected by the oleander and walnut leaf powders and maximum proline contents were in walnut extract $+20 \mathrm{ppm} \mathrm{IBA}$ and walnut extract (Table 4).

Table 4. Effects of growth regulators on total chlorophylls, carotenoids and proline contents of fourweek-old-seedlings of wheat grain under allelochemical stress due to oleander and walnut leaf powders.

\begin{tabular}{|c|c|c|c|}
\hline Treatments & $\begin{array}{l}\text { Total chlorophyll } \\
(\mathrm{mg} / \mathrm{g})\end{array}$ & $\begin{array}{l}\text { Carotenoid } \\
(\mathrm{mg} / \mathrm{g})\end{array}$ & $\begin{array}{l}\text { Proline } \\
(\mu \mathrm{mol} / \mathrm{g} \mathrm{FW})\end{array}$ \\
\hline Powder +0 & $0.582 \pm 0.010$ & $1.303 \pm 0.006$ & $8.027 \pm 0.147$ \\
\hline Powder $+10 \mathrm{ppm} \mathrm{GA}_{3}$ & $0.717 \pm 0.051^{* *}$ & $1.472 \pm 0.010^{* *}$ & $6.373 \pm 0.127^{* *}$ \\
\hline Powder $+20 " \mathrm{GA}_{3}$ & $0.463 \pm 0.034^{* *}$ & $1.291 \pm 0.004 * *$ & $8.774 \pm 0.136^{* *}$ \\
\hline Powder +10 " IBA & $0.512 \pm 0.012 * *$ & $1.251 \pm 0.029^{* *}$ & $8.877 \pm 0.100 * *$ \\
\hline Powder +20 " IBA & $0.447 \pm 0.050^{* *}$ & $1.221 \pm 0.071^{* *}$ & $12.930 \pm 0.227 * *$ \\
\hline Powder +0 & $0.481 \pm 0.016$ & $1.112 \pm 0.032$ & $5.614 \pm 0.065$ \\
\hline Powder +10 ppm $\mathrm{GA}_{3}$ & $0.548 \pm 0.021 * *$ & $1.135 \pm 0.118$ & $4.247 \pm 0.098 * *$ \\
\hline Powder $+20 " \mathrm{GA}_{3}$ & $0.247 \pm 0.033^{* *}$ & $0.899 \pm 0.006^{* *}$ & $4.293 \pm 0.039 * *$ \\
\hline Powder +10 " IBA & $0.385 \pm 0.001 * *$ & $1.088 \pm 0.040$ & $4.557 \pm 0.051 * *$ \\
\hline Powder +20 " IBA & $0.299 \pm 0.007^{* *}$ & $0.907 \pm 0.056^{* *}$ & $4.626 \pm 0.014 * *$ \\
\hline $\begin{array}{l}\text { Control (Seeds with distilled } \\
\text { water only) }\end{array}$ & $0.758 \pm 0.027^{* *}$ & $1.341 \pm 0.007^{* *}$ & $4.672 \pm 0.082 * *$ \\
\hline $\mathrm{LSD}_{0.01}$ & 0.022 & 0.123 & 0.256 \\
\hline $\mathrm{LSD}_{0.05}$ & 0.017 & 0.091 & 0.190 \\
\hline
\end{tabular}

LSD test was applied. * and $* *$ indicate at significant $\mathrm{p}<0.05$ and 0.01 , respectively.

In general, allelochemicals are known to inhibit plant growth by reducing chlorophyll and protein contents (Kocaçalışkan et al. 2009, Singh and Rao 2003). Elongation and fresh dry weights (Table 3) and total chlorophyll, carotenoid contents (Table 4) of four-week-old-seedlings of wheat were reduced by oleander and walnut leaf powder. Besides, the plant growth regulators alleviated this negative effects in this study (Tables 3,4). These results are supported by the findings of Terzi and Kocaçalışkan (2010). Pretratement of barley, wheat, cucumber, alfalfa and tomato seeds with $\mathrm{GA}_{3}$ and $\mathrm{Kn}$ or their combination, alleviated the inhibitory effect of juglone on seed germination and seedling growth. Proline increased under stress condition. The leaf powders of oleander and walnut increased proline content (Table 4). Similar results were indicated by Djanaguiraman et al. (2005) and Wang et al. (2009). This effect was alleviated significantly by 
$\mathrm{GA}_{3}$ (Table 4). The alleviation effect of $\mathrm{GA}_{3}$ was stronger than that of IBA (Tables 1, 3, 4). Similarly, $\mathrm{GA}_{3}$ was found more effective than $\mathrm{Kn}$ in alleviation of juglone stress (Terzi and Kocaçalışkan 2009).

In conclusion, this study suggests that $\mathrm{GA}_{3}$ and IBA protect protein and chlorophyll synthesis and prevent proline accumulation against oleander and walnut inhibitory effect. Especially $10 \mathrm{ppm}$ $\mathrm{GA}_{3}$ treatments induced protection against allelochemical stress due to walnut and oleander leaf (extract and powder) on wheat. $\mathrm{GA}_{3}$ possesses the antagonistic activity against allelochemicals of plant growth retardant nature and hence can be used to alleviate their detrimental effects. This may be beneficial practically in arragement of intercropping system(s) of the sensitive species between walnut and neriander plants in the same field and useful for agriculture and landscape.

\section{Acknowledgement}

The author would like to thank the authority of C.E.V. Alanya Hamdullah Emin Pasa Private Schools for providing funds, materials and lab space.

\section{References}

Abdul-Baki AA and Anderson JD 1973. Vigor determination in soybean seed by multiple criteria. Crop Sci. 13: $630-633$.

Bates LS, Waldern RP and Teare ID 1973. Rapid determination of free proline for water-stress studies. Plant Soil 39: 205-207.

Djanaguiraman M, Vaidyanathan R, Sheeba JA, Devi DD and Bangarusamy U 2005. Physiological responses of Eucalyptus globulus leaf leachate on seedling physiology of rice, Sorghum and Blackgram, Int. J. Agri. Biol. 7(1): 35-38.

Hoagland DR and Arnon DI 1950. The water culture method for growing plants without soil. Calif. Agric. Expt. St. Circ. 347: 1-32.

Inderjit and Malik AU 2002. Chemical Ecology of Plants: Allelopathy in Aquatic and Terrestrial Ecosystems. Birkhauser-Verlag, Berlin, pp. 272.

Kazincki G, Mikulas J, Hunyadi K and Horvath J 1997. Allelopathic effects of weeds on growth of wheat, sugarbeet and Brassica napus. Allelopathy J. 4: 335-340.

Lichtenthaler HK 1987. Method. Enzymol. 148: 350-382.

Matok H, Leszczynski B, Chrzanowski G and Sempruch C 2009. Effects of walnut phenolics on germination of dandelion seeds. Allelopathy J. 24(1): 177-182.

Putnam AR 1985. Weed allelopathy. In: Duke S.O. (ed.): Weed Physiology. Vol. 1. Reproduction and Ecophysiology. CRC Press, Boca Raton.

Qian L, Jing C, Zaimin J and Shuoxin Z 2010. Allelopathic effects of walnut leaves leachate on seed germination, seedling growth of medicinal plants. Allelopathy J. 26(2).

Rajyalakshmi M, Amruthkumar N, Divyashree NR, Kiran K, Pavithra GS, Rohini B, Sangeeta A and Sindhu S 2011. Inhibitory effects of Nerium oleander L. and its compounds, rutin and quercetin on Parthenium hysterophorus L.J. Agric. Sci. 3(2): 123-137.

Rice EL 1984. Allelopathy. Academic Press, Orlando, Florida, pp. 422.

Saberi M, Shahriari A, Tarnian F, Jafari M and Safari H 2011. Influence of some chemical compounds on germination and early seedling growth of two range species under allelopathic conditions. Front. Agric. China 5(3): 310-321.

Singh D and Rao YB 2003. Allelopathic evaluation of Andrographis paniculata aqueous leachates on rice (Oryza sativa L.). Allelopathy J. 11: 71-6.

Terzi I and Kocaçalışkan I 2009. Alleviation of juglone stress by plant growth regulators in germination of cress seeds. Sci. Res. Essays 4(5): 436-439. 
Terzi I and Kocaçalışkan I 2010. The effects of gibberellic acid and kinetin on overcoming the effects of juglone stress on seed germination and seedling growth, Turk J. Bot. 34: 67-72.

Turk MA and Tawaha AM 2002. Inhibitory effects of aqueous exracts of black mustard on germination and growth of lentil. Pak. J. Agron. 1: 28-30.

Uygur FN and Iskenderoglu N 1997. Allelopathic and bioherbicide effects of plant extracts on germination of some weed species. Turkish J. of Agriculture and Forestry 21: 177-180.

Wang JC, Wu Y, Wang Q, Peng YL, Pan KW, Luo P and Wu N 2009. Allelopathic effects of Jatropha curcas on marigold (Tagetes erecta L.). Allelopathy J. 24(1): 123-130.

Whittaker RH and Feeny PP 1971. Allelochemicals: Chemical interactions between species. Science 171: 757-770.

(Manuscript reveived on 5 December, 2012; revised on 18 May, 2013) 